\title{
PENGEMBANGAN DAN VALIDASI ANALISIS KUANTITATIF NATRIUM SEFTRIAKSON DENGAN MENGGUNAKAN METODE FTIR-ATR
}

\author{
Development and Validation of Quantitative Analysis of Sodium Ceftriaxone \\ using FTIR-ATR Method
}

\begin{abstract}
Rohimmahtunnissa Azhar, Saly Amaliacahya Aprilian, Raodatul Jannah, Susi Kusumaningrum, dan Firdayani
\end{abstract}

Pusat Teknologi Farmasi dan Medika, BPPT. Kompleks Puspiptek, Serpong.

Email: rohimmahtunnissa@bppt.go.id

\begin{abstract}
Abstrak
Seftriakson adalah salah satu antibiotik turunan Sefalosporin generasi ketiga. Analisis kuantitatif bahan baku seftriakson dalam sediaan natrium seftriakson pada umumnya menggunakan metode KCKT. Pada metode KCKT relatif menggunakan pelarut tidak ramah lingkungan oleh karena itu dilakukan pendekatan dengan metode spektroskopi FTIR-ATR.Kelebihan metode ini relatif lebih cepat dalam preparasi dan waktu analisissampel dibandingkan metode KCKT, berbiaya rendah dan menggunakan pelarut ramah lingkungan. Validasi metode ditetapkan berdasarkan parameter linearitas, selektivitas, presisi, akurasi, limit deteksi dan limit kuantifikasi. Berdasarkan hasil validasi didapatkan linearitas dengan koefisien determinasi 0,9992 pada rentang konsentrasi $300-800 \mathrm{mg} / \mathrm{mL}$, limit deteksi sebesar $20,02 \mathrm{mg} / \mathrm{mL}$, dan limit kuantifikasi sebesar 60,68 mg/mL.Dengan demikian metode ini dapat dijadikan rekomendasi sebagai metode analisis dalamFarmakope Indonesia.
\end{abstract}

Kata kunci: natrium seftriakson, FTIR-ATR, validasi.

\begin{abstract}
Ceftriaxone is one of the third generation antibiotics of Cephalosporin. Quantitative analysis of Ceftriaxone in sodium ceftriaxone for injection usually uses HPLC method. This method mostly donot use an environmental friendly solvent,so this research aims to find the new approach for quantitative analysis using FTIR-ATR Spectroscopy. The advantages of this method are relatively faster in preparation and sample testing than HPLC method, low-cost analysis, and using environmental-friendly solvent. Validation method was determined by linearity, selectivity, precision, accuracy, limit of detection and limit of quantification. According to validation results, this method has linearity with $R$-square 0.9992 in range $300-800 \mathrm{mg} / \mathrm{mL}$ of concentration, $20.02 \mathrm{mg} / \mathrm{mL}$ in the limit of detection and $60.68 \mathrm{mg} / \mathrm{mL}$ in the limit of quantification. So that, quantitative analysis of sodium ceftriaxone in sodium ceftriaxone for injection using FTIR-ATR method was recommended for analysis method in Indonesia Pharmacopeia.
\end{abstract}

Kata kunci: Sodium Ceftriaxone, FTIR-ATR, validation.

\section{PENDAHULUAN}

Seftriakson merupakan salah satu antibiotic turunan sefalosporin generasi tiga yang berfungsi untuk mengobati berbagai infeksi yang disebabkan oleh organisme pada bagian tulang dan sendi, perut, saluran pernafasan bagian bawah, meningitis, daerah panggul, kulit, jaringan lunak, dan salurankemih. Selain itu, juga efektif dalam mengobati artritisseptik, bakteremia, dan gonorhea yang disebabkan oleh organisme yang rentan terhadap antibiotik. Seftriakson berguna dalam pencegahan infeksi ostoperatif, tetapi tidak lebih efektif daripada turunan sefalosporin generasi pertama dan kedua (Owens, 2003).

Seftriakson biasanya tersedia dalam bentuk garamnya yakni natrium seftriakson yang berwarna putih sedikit kekuningan. Produk seftriakson dipasarkan dalam bentuk sediaan natrium seftriakson untuk injeksi berupa serbuk berbobot 1 gram. Setiap 1 gram produk mengandung seftriakson minimal $77,6 \mu \mathrm{g} / \mathrm{mg}$ dan kadar seftriakson anhidrat berada pada rentang $90-115 \%$.

Analisis kandungan seftriakson biasanya menggunakan metode Kromatografi Cair Kinerja Tinggi (KCKT) berdasarkan US Pharmacopeia.Metode KCKT menggunakan pelarut organik yang dapat mencemari lingkungan seperti asetonitril, larutan buffer, dantetrahepthylammonium bromide (THAB), trietilamonimum asetat (Trindade, 2018). Sehingga untuk mengurangi penggunaan pelarut berbahaya maka dilakukan pendekatan analisis kuantitatif menggunakan 
metode spektroskopi Fourier-Transform Infra $\operatorname{Red}(\mathrm{FTIR})$. Trindade (2017) melaporkan pengembangan metode kuantifikasi natrium seftriakson menggunakan FTIR dengan pendispersi sampel berupa $\mathrm{KBr}$. Metode ini memiliki linearitas pada konsentrasi $0,4-1,2$ $\mathrm{mg}$ dengan koefisien determinasi sebesar 0,9983, limit deteksi $0,016 \mathrm{mg}$ dan limit kuantifikasi 0,049 mg.

Pada penelitian kali ini metode FTIR yang dikembangkan menggunakan ATR (Attenuated TotalReflectance) dengan tujuan meminimalisir penggunaan bahan preparasi sampel. Natrium seftriakson dilarutkan dalam air destilasi dengan konsentrasi tertentu, dianalisis dengan menggunakan ATR yang kemudian dihitung luas area puncak gugus karbonil.

Analisis kuantifikasi natrium seftriakson selanjutnya divalidasi berdasarkan luas area absorbansi. Hal-hal yang dijadikan penentuan dalam validasi diantaranya: selektivitas, linearitas, presisi, akurasi, limit deteksi dan limit kuantifikasi.

\section{TINJAUAN PUSTAKA}

Antimikroba atau yang biasa dikenal antibiotic merupakan salah satu obat yang sangat penting di dunia untuk mencegah infeksi bakteri (Consortti, 2017). Antibiotik dapat membunuh/menghancurkan bakteri yang masuk ke dalam tubuh tanpa membahayakan induknya, yaitu manusia (Kourkouta, 2017). Salah satu jenis antibiotik yang banyak digunakan saat ini adalah jenis antibiotic Sefalosporin. Sefalosporin merupakan kelompok antibiotik $\beta$-laktam semi-sintetis (Ribeiro, 2018) yang merupakan turunan dari Sefalosporin-C (Manchi, 2014; Zala, 2015). Sefalosporin merupakan senyawa $\beta$-laktam yang mencegah sintesis dari dinding sel bakteri (Cheng, 2017) dengan cara menghubungkan protein pengikat penisilinnya ke dalam membran bakteri sehingga menyebabkan lisis sel dan kematian bakteri (Ribeiro,2018). Sefalosporin diklasifikasikan ke dalam lima generasi yang aktif dalam menghambat bakteri gram positif maupun negatif. Generasi pertama, kedua, dan ketiga aktif dalam menghambat bakteri gram negatif. Generasi keempat aktif menghambat bakteri gram positif dan bakteri gram negatif. Sementara itu, generasi kelima merupakan generasi terbaru yang berkembang saat ini (Masoud, 2014).

Seftriakson merupakan salah satu derivate sefalosporin yang termasuk dalam generasi ketiga (Trindade, 2017). Seftriakson bermanfaat untuk mengobati berbagai macam infeksi di antaranya infeksi pernapasan, saluran urin, tulang dan sendi, meningitis dan juga digunakan dalam operasi beda profilaksis. Seftriakson banyak digunakan karena spektrumnya yang luas dalam aktivitas antibakterinya serta jarang terjadi efek samping dalam penggunaannya (Abu Teir, 2014). Seftriakson memiliki bentuk garamnya dengan rumus molekul $\mathrm{C}_{18} \mathrm{H}_{16} \mathrm{~N}_{8} \mathrm{Na}_{2} \mathrm{O}_{7} \mathrm{~S}_{3} \cdot 3,5 \mathrm{H}_{2} \mathrm{O}$ dan berat molekul 661,60 (Khan, 2017). Struktur molekul dari Natrium Seftriakson ditampilkan pada Gambar 1.

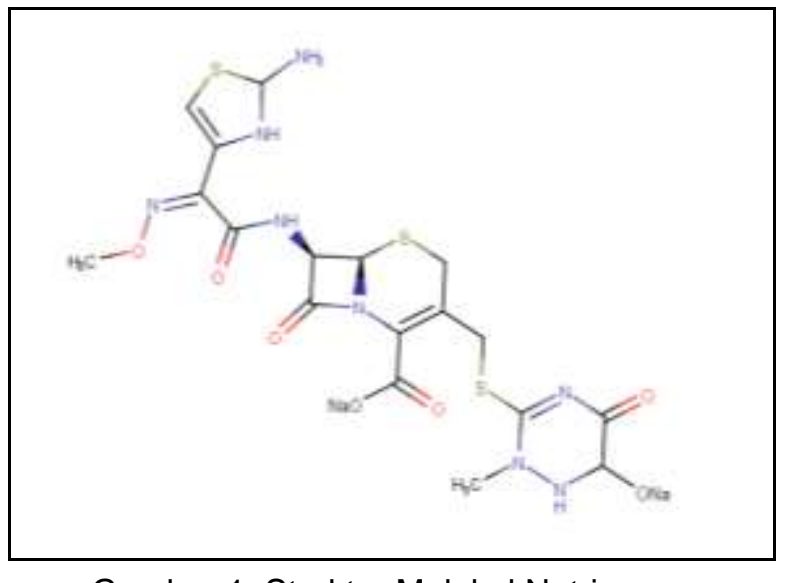

Gambar 1. Struktur Molekul Natrium
Seftriakson

Natrium Seftriakson dapat diproduksi dengan mereaksikan senyawa MAEM (2Mercaptobenzothiazolelyl(z)-2-aminothiazol-4yl-2-methoxyimino acetate) dan 7-ACT (7Amino Ceftriaxone Sodium) kemudian ditambahkan dengan sumber natrium. Reaksi tersebut akan membentuk Natrium Seftriakson dalam bentuk disodium hemiheptahydrate. Dalam struktur molekul Natrium Seftriakson tersebut terbentuk suatu gugus karbonil. Struktur molekul dari senyawa MAEM dan 7ACT ditampilkan pada Gambar 2 dan Gambar 3.

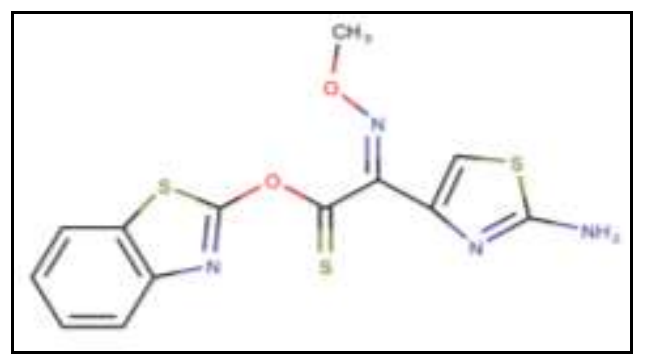

Gambar 2. Struktur Molekul Senyawa MAEM 
Pengembangan dan ValidasI Analisis Kuantitatif Natrium Seftriakson dengan Menggunakan Metode FTIR-ATR (Rohimmahtunnissa Azhar, Saly Amaliacahya Aprilian, Raodatul Jannah, Susi Kusumaningrum, dan Firdayani)

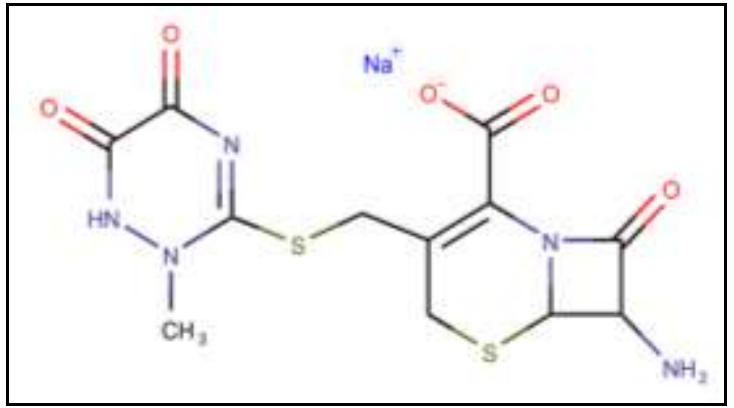

Gambar 3. Struktur Molekul Senyawa 7-ACT

Spektroskopi inframerah atau yang biasa juga disebut dengan spektroskopi vibrasi adalah salah satu metode standar yang digunakan dalam analisis farmasi dan kimia, yang menyediakan gambar dari vibrasi atom dalam senyawa (Rakesh, 2014). Salah satu metode spektroskopi inframerah adalah dengan menggunakan alat FTIR. FTIR merupakan salah satu cara analisis yang dapat digunakan untuk karakterisasi sampel dalam bentuk cair, larutan, dan bubuk (Nandiyanto, 2019). Analisis menggunakan FTIR tidak memerlukan penambahan pewarna ataupun label untuk visualisasi dari komponen kimia yang berbeda dalam sampel (Kazarian, 2006; Grumezescu, 2018). FTIR mengukur semua panjang gelombang secara bersamaan sehingga terbentuk spectrum transmittansi atau absorbansi (Vieira, 2012). Salah satu jenis FTIR yang dapat digunakan untuk kuantifikasi Natrium Seftriakson adalah ATR. ATR ini merupakan teknik analisis yang didasarkan pada vibrasi molekul dan pembelokan cahaya ketika melewati media yang berbeda (Kassis, 2010). FTIR ATR ini memiliki kelebihan yaitu hanya memerlukan sedikit sampel untuk dianalisis (Kazarian, 2006). Spektrum yang dihasilkan dalam analisis dengan menggunakan FTIR adalah spektrum yang berada pada rentang panjang gelombang $4000-400 \mathrm{~cm}^{-1}$ (Rakesh, 2014).

Analisis Natrium Seftriakson dapat dilakukan dengan menggunakan FTIR-ATR dengan menghitung luas puncak dari spectrum gugus karbonil yang dihasilkan, yaitu pada rentang panjang gelombang 1800 $1700 \mathrm{~cm}^{-1}$ (Trindade, 2017). Metode analisis kuantitatif dari Natrium Seftriakson memerlukan adanya validasi sesuai dengan syarat ICH (International Council for Harmonization). Untuk validasi metode analisis kuantitatif, maka diperlukan parameter berupa :

a) Linearitas

Parameter linearitas didapatkan dengan membuat larutan sampel dengan kadar yang berbeda untuk membuat grafik regresi linear dari absorbansi terhadap konsentrasi.

b) Presisi

Presisi dievaluasi berdasarkan keterulangan dari salah satu konsentrasi pada hasil linearitas dalam satu hari yang sama dan dengan perlakuan yang sama. Pada parameter ini dapat dianalisis nilai RSD-nya (relative standard deviation).

c) Akurasi

Akurasi dievaluasi dengan melakukan pengulangan analisis sebanyak tiga kali pada suatu konsentrasi sampel oleh dua analis berbeda sehingga didapatkan nilai recovery.

d) Selektivitas

Selektivitas dari metode ditentukan dengan menganalisis spectrum dari pelarut dan memastikan bahwa tidak ada interferensi pelarut dalam kuantifikasi sampel.

e) Limit DeteksidanKuantifikasi

Limit deteksi (LOD) dan kuantifikasi (LOQ) dihitung berdasarkan pada intercept standar deviasi dan slope dari kurva. Nilai LOD dan LOQ dapat dihitung dengan menggunakan persamaan (1) dan (2).

$$
\begin{aligned}
& L O D=3,3\left(\frac{S D}{a}\right) \\
& L O Q=10\left(\frac{S D}{a}\right)
\end{aligned}
$$

Dimana :

$$
\begin{array}{ll}
\mathrm{a} & =\text { slope kurva } \\
\mathrm{SD} & =\text { intercept standardeviasi }
\end{array}
$$

(Consortti, 2017; Vieira, 2012; Trindade, 2017; Rohman, 2014)

Padap enelitian yang dilakukan oleh Kassis, et al. (2010) yang telah mengembangkan metode in situ dengan menggunakan ATR-IR untuk memonitor disolusi produk farmasi, didapatkan akurasi hingga $\pm 3 \%$. Selain itu, juga didapatkan bahwa sistem ATR-IR memiliki sensitivitas yang bagus dan dapat menganalisis sampel hingga konsentrasi terendah mencapai 0,03 $\mathrm{mg} / \mathrm{mL}$.

\section{METODE PENELITIAN}

Bahan yang digunakan dalam penelitian ini adalah prototipe working standar natrium seftriakson BPPT yang telah dibandingkan dengan standar primer US Pharmacopeia. Sampel natrium seftriakson dilarutkan dalam air destilasikemudian dianalisis dengan instrumen FTIR seri Nicolet iS10pada rentang spektrum $4000-400 \mathrm{~cm}^{-1}$, resolusi 8 dan 
interval $1 \mathrm{~cm}^{-1}$. Luas area absorbansi gugus karbonil pada rentang spektrum 1800-1700 $\mathrm{cm}^{-1}$ dihitung berdasarkan parameter validasi yang dilakukan sebagai berikut.

a) Parameter linearitas yang didapat berupa koefisien determinasi, LOD dan LOQ dengan variabel konsentrasi $300 \mathrm{mg} / \mathrm{mL}$, $400 \mathrm{mg} / \mathrm{mL}, 500 \mathrm{mg} / \mathrm{mL}, 600 \mathrm{mg} / \mathrm{mL}, 700$ $\mathrm{mg} / \mathrm{mL}$ dan $800 \mathrm{mg} / \mathrm{mL}$.

b) Parameter presisi yang didapat berupa \%R.S.D. dari 6 kali ulangan variabel konsentrasi $800 \mathrm{mg} / \mathrm{mL}$

c) Parameter akurasi yang didapat berupa \% recovery yang dilakukan oleh 2 orang analis menganalisis 3 kali ulangan untuk konsentrasi $500 \mathrm{mg} / \mathrm{mL}$ dan $700 \mathrm{mg} / \mathrm{mL}$ dengan perlakuan yang sama.

d) Parameter selektivitas ditentukan dengan membandingkan gugus puncak karbonil antara spektrum sampel dengan spektrum pelarut yang berupa air destilasi.

\section{HASIL DAN PEMBAHASAN}

Metode analisis kuantitatif menggunakan Spektroskopi Infra Merah dengan ATR dapat meminimalkan perlakuan dalam preparasi sampel danpenggunaan pelarut yang ramah lingkungan. Pada penelitian ini, natrium seftriakson dilarutkan dengan air untuk meminimalisir bias dalam proses preparasi.

Metode kuantifikasi natrium seftriakson telah divalidasi sesuai dengan syarat $\mathrm{ICH}$ meliputi selektivitas, linearitas, presisi, akurasi, limit deteksi dan limit kuantifikasi yang dijelaskan sebagai berikut.

\section{a) Selektivitas}

Kuantitas sampel ditetapkan berdasarkan luas area gugus karbonil pada rentang spektra $1800-1700 \mathrm{~cm}^{-1}$. Pada Gambar 4 terlihat bahwa pelarut yakni air,tidak menunjukkan adanya puncak pada rentang tersebut. Berbeda dengan Gambar 5, terlihat adanya puncak pada rentang 1800$1700 \mathrm{~cm}^{-1}$ yang merupakan gugus karbonil dari natrium seftriakson.

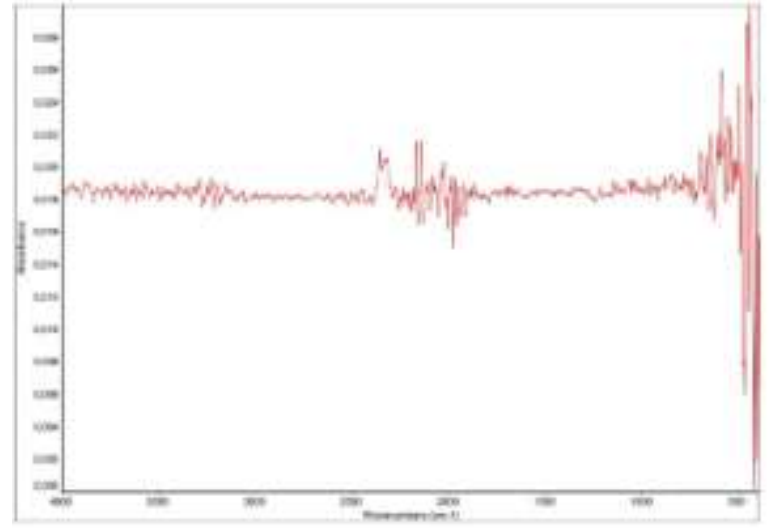

Gambar 4. Spektrum Pelarut

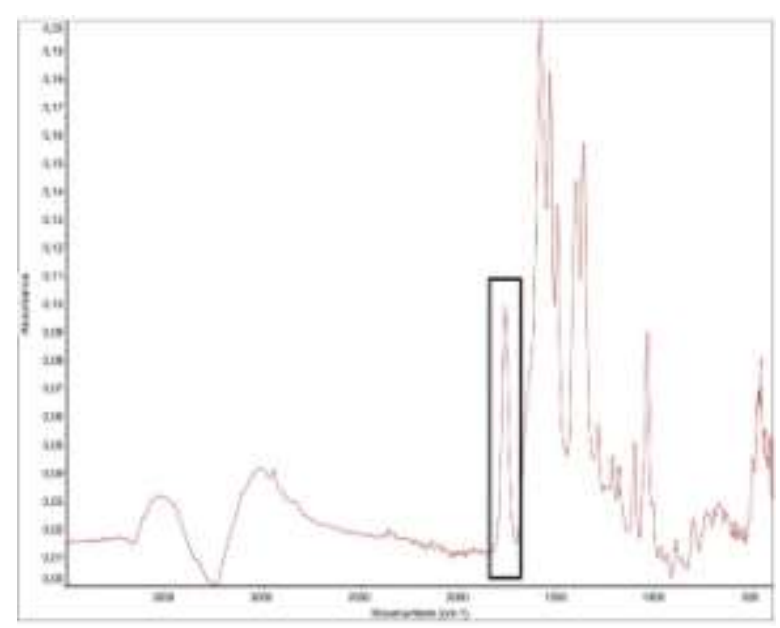

Gambar 5. Spektrum Sampel dalam

Fasa Cair

Sehingga dapat ditetapkan bahwa tidak ada intervensi dari spektrum pelarut yang dapat menyebabkan bias dalam perhitungan luas area absorbansi sampel.

b) Linearitas

Kurva linearitas pada rentang konsentrasi $300 \mathrm{mg} / \mathrm{mL}$ hingga $800 \mathrm{mg} / \mathrm{mL}$ menunjukkan linearitas yang baik dengan koefisien determinasi sebesar 0,9992. Nilai koefisien determinasi sesuai dengan syarat $\mathrm{ICH}$ sebesar 0,999 dan terlihat pada Gambar 6bahwa perbedaan luas area antar konsentrasi relatif kecil sehingga dengan nilai koefisien determinasi yang tinggi dapat meningkatkan ketepatan dalam pembacaan nilai sampel. Nilai pembacaan luas area yang kecil juga dipengaruhi oleh energi yang digunakan oleh instrumen FTIR-ATR hanya 70\% dibandingkan dengan FTIR-KBr. 
Pengembangan dan ValidasI Analisis Kuantitatif Natrium Seftriakson dengan Menggunakan Metode FTIR-ATR (Rohimmahtunnissa Azhar, Saly Amaliacahya Aprilian, Raodatul Jannah, Susi Kusumaningrum, dan Firdayani)

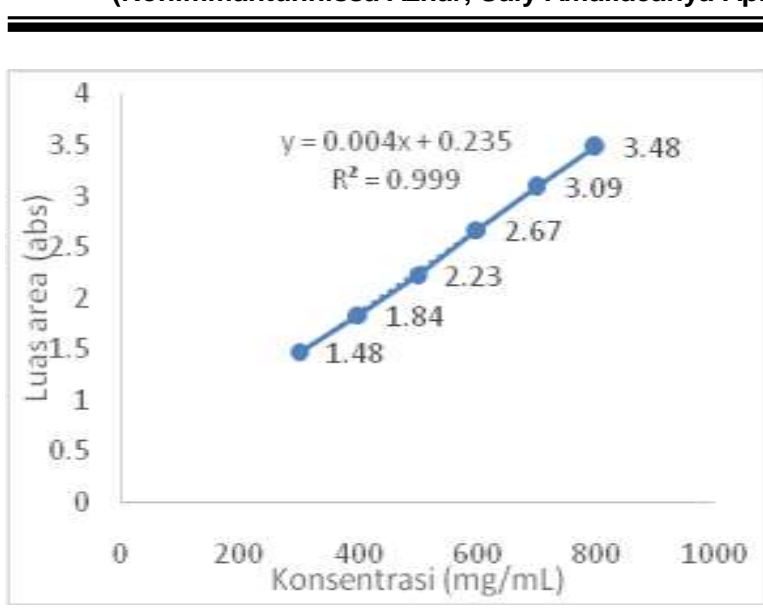

Gambar 6. Kurva linearitas Metode Kuantifikasi Bahan Baku Natrium Seftriakson

c) Presisi

Penentuan nilai presisi ditetapkan pada konsentrasi tertinggi yakni $800 \mathrm{mg} / \mathrm{mL}$ karena luas area yang relatif kecil berpengaruh pada ketepatan pembacaan sampel.

Tabel 1. Penentuan Presisi Metode Kuantifikasi Bahan Baku Natrium Seftriakson

\begin{tabular}{lcc}
\hline $\begin{array}{c}\text { Konsentrasi } \\
\mathbf{~ m g / m L}\end{array}$ & $\begin{array}{c}\text { Luas area } \\
\text { (abs) }\end{array}$ & $\begin{array}{c}\text { Recovery } \\
\text { ( } \mathbf{m g} / \mathbf{m L} \text { ) }\end{array}$ \\
\hline 800,02 & 3,47 & 789,00 \\
800,06 & 3,38 & 767,05 \\
800,10 & 3,41 & 774,37 \\
800,00 & 3,34 & 757,29 \\
800,04 & 3,43 & 779,24 \\
800,04 & 3,47 & 789,00 \\
\hline Rata-rata & \multicolumn{2}{c}{$\mathbf{7 7 5 , 9 9}$} \\
\hline Standar Deviasi & \multicolumn{2}{c}{$\mathbf{1 2 , 5 0}$} \\
\hline R.S.D. & \multicolumn{2}{c}{$\mathbf{1 , 6 1}$} \\
\hline
\end{tabular}

Pada Tabel 1 menunjukkan nilai R.S.D. sebesar $1,61 \%$ dimana kurang dari $2 \%$ dan sesuai dengan syarat $\mathrm{ICH}$.

d) Akurasi

Penentuan akurasi dilakukan pada dua konsentrasi yang berbeda. Pada Tabel 2 terlihat bahwa konsentrasi $500 \mathrm{mg} / \mathrm{mL}$ memiliki recovery $104 \%$ dan pada konsentrasi $700 \mathrm{mg} / \mathrm{mL}$, sebesar 101 \%.Sedangkan $\mathrm{ICH}$ mensyaratkan dalam kisaran 98-102\% maka hanya pada konsentrasi $700 \mathrm{mg} / \mathrm{mL}$ yang masuk ke dalam syarat tersebut. Hal ini dikarenakan semakin kecil konsentrasi sampel akan semakin kecil luas area absorbansi dimana luas area yang kecil dipengaruhi oleh pemakaian energi ATR sebesar $70 \%$.
Tabel 2. Penentuan Akurasi Metode Kuantifikasi Bahan Baku Natrium Seftriakson

\begin{tabular}{cccc}
\hline Analis & $\begin{array}{c}\text { Konsentrasi } \\
(\mathbf{m g} / \mathbf{m L})\end{array}$ & $\begin{array}{c}\text { RSD } \\
(\%)\end{array}$ & $\begin{array}{c}\text { Recovery } \\
(\%)\end{array}$ \\
\hline \multirow{2}{*}{ Analis 1 } & 500 & 0,72 & 105 \\
& 700 & 0,73 & 100 \\
\multirow{2}{*}{ Analis 2 } & 500 & 1,00 & 103 \\
& 700 & 1,77 & 102 \\
\hline
\end{tabular}

Sehingga pengukuran kadar sebaiknya dilakukan pada konsentrasi tinggi untuk menghindari nilai simpangan yang besar dengan mengingat sifat kelarutan natrium seftriakson dalam air sebesar $40 \mathrm{gram} / 100$ $\mathrm{mL}$ pada temperatur $25^{\circ} \mathrm{C}$.

e) Limit deteksi dan limit kuantifikasi

Metode kuantifikasi ini memiliki nilai limit deteksi yaitu sebesar $20,02 \mathrm{mg} / \mathrm{mL}$ yang menunjukkan batas konsentrasi alat dapat mengukur sejumlah sampel. Selain itu, nilai limit kuantifikasi yang didapat sebesar60,68 $\mathrm{mg} / \mathrm{mL}$ yang menunjukkan batas kadar terendah dalam sampel yang dapat diukur oleh alat.Sebagai contoh dalam aplikasi injeksi intramuskular, sediaan natrium seftriakson sebanyak 1 gram dilarutkan ke dalam $3,5 \quad \mathrm{~mL}$ air steril menghasilkankonsentrasi sebesar 285,71 $\mathrm{mg} / \mathrm{mL}$. Konsentrasi inimelebihi nilai limit kuantifikasi sehinggadapat dianalisis dengan metode FTIR-ATR ini.

\section{KESIMPULAN}

Berdasarkan hasil penelitian didapatkan koefisien determinasi 0,9992, R.S.D. presisi $1,61 \%$, recovery akurasi $104 \%$ untuk konsentrasi $500 \mathrm{mg} / \mathrm{mL}$ dan $101 \%$ untuk konsentrasi $700 \mathrm{mg} / \mathrm{mL}$. Metode kuantifikasi ini telah memenuhi syarat $\mathrm{ICH}$, ramah lingkungan dan waktu preparasi sampel lebih singkat.

\section{UCAPAN TERIMA KASIH}

Semua penulis berkontribusi sama dalam penelitian, berdiskusi dan berperan aktif dalam setiap tahap penulisan manuskrip. Penulis mengucapkan terima kasih kepada KEMENRISTEK-DIKTI yang telah mendanai penelitian ini melalui program Insentif Sinas tahun 2019. 


\section{DAFTAR PUSTAKA}

Abu Teir, M.M., Ghithan, J., Abu-Taha, M.I., Darwish, S. M., \& Abu-Hadid, M.M. (2014). Spectroscopic Approach of the Interaction Study of Ceftriaxone and Human Serum Albumin. Journal of Biophysics and Structural Biology, 6(1), 1-12.

Ali, H. R. H., Ali, R., Batakoushy, H. A., \&Derayea, S. M. (2017). Solid-State FTIR Spectroscopic Study of Two Binary Mixtures: CefepimeMetronidazole and CefoperazoneSulbactam. Journal of Spectroscopy, 16.

Cheng, I. Y., Xia, W., Zhang, X., Bai, A. M. Ouyang, Y., \& Hu, Y. J. (2017). In Vitro Binding Comparison of Cephalosporins to Human Serum Albumin by Spectroscopy and Molecular Docking Approaches: A Novel Structural Pursuing. Journal of Molecular Liquids, 248, 168-176.

Consortti, L. P. \& Salgado, H. R. N. (2017). Green Method for Quantification of Sodium Cefotaxime in Lyophilized Powder by Infrared Spectroscopy, J Pharm SciEmerg Drugs 5: 1.

Grumezescu, A. M. (2018). Nanoscale Fabrication, Optimization, Scale-Up, and Biological Aspects of Pharmaceutical Nanotechnology. United Kingdom: Elsevier, Inc.

Kassis, A., Bhawtankar, V.M., \& Sowa Jr., J.R. (2010). Attenuated Total Reflection Infrared Spectroscopy (ATR-IR) as an In Situ Technique for Dissolution Studies. Journal of Pharmaceutical and Biomedical Analysis, 53, 269-273.

Kazarian, S. G. \& Chan, K. L. A. (2006). Applications of ATR-FTIR Spectroscopic Imaging to Biomedical Samples. BiochimicaetBiophysicaActa 1758, 858867.

Khan, M. Y., Roy, M., Rawal, R. K., \& Bansal, U. K. (2017). A Review: Ceftriaxone for Life. Asian Journal of Pharmaceutical Research, 7(1), 35-48.

Kourkouta, L., Kotsiftopoulos, C. H., Papageorgiou, M., Iliadis, C. H., \&Monios, A. (2017). The Rational Use of Antibiotics Medicine. Journal of Healthcare Communications, 2(3), 27.

Manchi, H., Kudagi, B. L., Buchineni, M., Jithendra, K., Chandra, V. B., Pathapati, R. M., Kumar, M. R., \& Devi, N. A. (2014). Cephalosporin Resistance
Pattern in a Tertiary Care Hospital: An Observation Study. International Journal od Current Microbiology and Applied Sciences, 3(12), 718-725.

Masoud, M. S., Ali, A. E., \& Nasr, N.M. (2014) Review Article Chemistry, Classification, Pharmacokinetics, Clinical Uses and Analysis of Beta Lactam Antibiotics: A Review. Journal of Chemical and Pharmaceutical Research, 6(11), 28-58.

Naguib, I. A. \&Darwish, H. W. (2016). Determination of Cefoperazone Sodium in Presence of Related Impurities by Improved Classical Least Squares Chemometric Methods: A Comparative Study. Journal of Chemistry, 1-8.

Nandiyanto, A. B. D., Oktiani, R., \&Ragadhita, R. (2019). How to Read and Interpret FTIR Spectroscope of Organic Materials. Indonesian Journal of Science \& Technology, 4(1), 97-118.

Owens, H. M. \& Dash, A. K. (2003). Ceftriaxone Sodium Comprehensive Profile. Omaha: Elsevier Inc.

Rakesh, P., Charmi, P., \& K.S., Rajesh. (2014). Quantitative Analytical Applications of FTIR Spectroscopy in Pharmaceutical and Allied Areas. Journal of Advanced Pharmacy Education \& Research, 4(2), 145-157.

Ribeiro, A. R., Sures, B., \& Schmidt, T. C (2018). Cephalosporin Antibiotics in the Aquatic Environment: A Critical Review of Occurrence, Fate, Ecotoxicity, and Removal Technologies. Environmental Pollution, 241, 1153-1166.

Rohman, Abdul. (2014). Statistika dan Kemometrika Dasar dalam Analisis Farmasi. Yogyakarta: Pustaka Bogor.

Trindade, M. T. \& Salgado, H. R. N. (2017). Development and Validation for the Quantification of Ceftriaxone Sodium in Powder for Injection by Infrared Spectroscopy. Physical Chemistry, 7(3), 55-62.

Trindade, M. T. \& Salgado, H. R. N. (2018). A Critical Review of Analytical Methods for Determination of Ceftriaxone Sodium. Critical Reviews in Analytical Chemistry, ISSN: 1547-6510.

Vieira, D.C.M., Ricarte, P.C., \& Salgado, H. R. N. (2012). Development and Validations of Quantitative Analysis of Cefuroxime Sodium in Powder for Injection by Infrared Spectroscopy. Advances in Analytical Chemistry, 2(6), 80-87. 
Pengembangan dan ValidasI Analisis Kuantitatif Natrium Seftriakson dengan Menggunakan Metode FTIR-ATR (Rohimmahtunnissa Azhar, Saly Amaliacahya Aprilian, Raodatul Jannah, Susi Kusumaningrum, dan Firdayani)

Zala, A. C., Malam, P., Manvar, R., Patel, D., Patel, D., \&Kantharia, N. D. (2015). Superbugs Against Cephalosporin: Observational Study at Tertiary Care
Hospital in India. European Journal of Pharmaceutical and Medical Research, 2(5), 1232-1241. 
